\title{
PARA OS QUE DESEJAM ENTENDER A GESTÃO DA INFORMAÇÃO
}

PONJUÁN DANTE, Glória. Gestión de Información en las organizaciones: princípios, conceptos y aplicaciones. Santiago de Chile : CECAPI, 1998. 222 p.

Ao iniciar seu livro com a distinção entre dado, informação, conhecimento e inteligência, Glória Ponjuán já subverte, deliciosamente aliás, a tradicional abordagem de sistemas de informação, normalmente voltada para o desenvolvimento de coleções de documentos que devem ser coletados, tratados, armazenados e distribuídos.

A cada página, a autora nos desafia a refletir sobre a função crítica do planejamento, da organização, da direção, do controle e da avaliação das atividades voltadas para a utilização da informação como recurso. Compreendida desta maneira, cabe ao profissional responsável por unidades de informação e bibliotecas o desafio de mapear o ciclo de vida da informação e torná-la, como a própria autora refere em suas palestras, o "óleo lubrificante" a permear e permitir o fluxo suave e necessário das informações em quaisquer espaços e organizações.

Questionar se a palavra "Gestão" está "na moda" é de somenos importância, quando se reconhece que, em uma sociedade onde as instituições se tornam cada vez mais complexas em suas atividades, a qualidade e o valor agregado a produtos e serviços de informação torna-se crucial para a sobrevivência de indivíduos e grupos.

Afinal.. o que é "gerir" informação em ambientes em mutação ou naqueles em que a resistência a mudanças é parte da cultura da organização? A autora, agregando sua experiência prática a uma habilidade didática exemplar, apresenta os principais conceitos embutidos na proposta de "gestão", no caso, da informação.

Nessa etapa, o texto orienta-se para explicações sobre gestão da qualidade total, funções de marketing, gestão de recursos humanos, entre outros. Destaca a importância estratégica dos processos de liderança, da inteligência cooperativa nas organizações, da reengenharia, das Intranets e do benchmaking. Todos estes são tópicos atuais e relevantes no contexto da admi- 
nistração, informação ela mesma, e das unidades de informação e bibliotecas. A apresentação de uma metodologia para identificar os recursos de informação de uma organização (infomapping), igualmente, revela a intenção, por parte da autora, de mostrar um como-fazer ao profissional da informação interessado em aplicar princípios de gestão à sua prática. Ao finalizar sua preciosa e consistente contribuição, Ponjuán destaca o papel dos "atores das mudanças", responsáveis pela efetivação do apresentado e discutido ao longo da obra. Assim, quando chegamos à última linha da última página do texto, é que percebemos que o fato de o livro estar escrito em espanhol é, também, de somenos importância.

Cabe ressaltar que a divisão da obra em capítulos (seguidos das suas respectivas referências bibliográficas) permite uma leitura independente do todo, e a presença de um índice de assuntos e autores reforça o cuidado da autora em dirigir sua "fala" diretamente ao leitor. Por essas e outras abordagens, que o espaço de uma resenha nos impede de explorar mais a fundo, esta obra engloba, de forma extremamente didática e instigante, um conteúdo indispensável para os que realmente desejam atuar como gerentes de recursos de informação e se interessam pelos paradigmas propostos.

\section{Patrícia Zeni Marchiori}

Doutora em Ciências da Informação pela ECA/ USP. Professora do Departamento de Ciência e Gestão da Informação da Universidade Federal do Paraná.

pzeni@coruja.humanas.ufpr.br

\section{Title}

For those who wish to understand the Information Management

\section{Título}

Para los que desean entender la gestión de la información 